\title{
Anemia sebagai Faktor Risiko Peningkatan Skor Kehamilan Berdasarkan Kartu Skor Poedji Rochjati
}

\author{
Siska Ditaningtias', Agus Sulistiyono ${ }^{2}$, Rachmah Indawati ${ }^{3}$ \\ 'Program Studi Magister Ilmu Kesehatan Masyarakat Fakultas Kesehatan Masyarakat Universitas Airlangga Surabaya \\ ${ }^{2}$ Satgas Penakib (Sekretariat POGI) Divisi Feto Maternal RSUD Dr Soetomo Surabaya \\ ${ }^{3}$ Departemen Biostatistika Fakultas Kesehatan Masyarakat Universitas Airlangga Surabaya
}

\section{ABSTRAK}

Tujuan: Menganalisis 28 faktor risiko ditambah dengan 4 faktor risiko dari register kohort ibu, yang dominan mengakibatkan peningkatan skor Poedji Rochjati atau peningkatan kategori kehamilan.

Bahan dan Metode: Ini adalah penelitian data sekunder secara cross sectional yang dilakukan pada bulan Agustus - November 2014, menggunakan data dari register kohort ibu tahun 2009 2013 wilayah Kerja Puskesmas Kebonsari Kabupaten Madiun. Teknik pengumpulan data adalah menggunakan Kartu Skor Poedji Rochjati yang skornya sudah ada pada register kohort ibu. Populasi adalah semua ibu hamil yang ada pada register kohort ibu Puskesmas Kebonsari tahun 2009 - 2013. Sampel diambil dengan rumus penghitungan sampel penelitian survey cross sectional secara proporsi dan sesuai dengan kriteria inklusi sejumlah 147 ibu hamil.

Hasil: Dari 32 faktor risiko yang dianalisis, hanya 8 yang mempunyai pengaruh meningkatkan skor Poedji Rochjati, dan hanya 1 yang bermakna secara statistik yaitu kurang darah (anemia). Dari 8 faktor risiko, anemia adalah faktor risiko terbesar yang mempu meningkatkan skor Poedji Rochjati seorang ibu hamil sepanjang kehamilannya. Berikut nilai ke depalan faktor risiko tersebut : anemia $(6,737)$, jumlah Ante Natal Care $(3,474)$, terlalu banyak anak $(1,261)$, terlalu cepat hamil lagi $(1,167)$, terlalu tua $(1,146)$, pernah gagal kehamilan $(1,114)$, Indeks Massa Tubuh $(1,107)$, terlalu lama hamil lagi $(1,051)$.

Simpulan: Ibu hamil dengan anemia mempunyai risiko sebesar 6,737 kali untuk mengalami peningkatan skor dibandingkan dengan ibu hamil yang tidak anemia.

Kata Kunci: kehamilan risiko rendah, kehamilan risiko tinggi, kehamilan risiko sangat tinggi, peningkatan skor Poedji Rochjati, Kartu Skor Poedji Rochjati.

\begin{abstract}
Objectives: to anlayze 28 of risk factors, plus 4 of risk factors from register cohort of mothers, which dominant can caused increase Poedji Rochjati Score or increase pregnancy category. Materials and Methods: This was a secondary data research cross sectional conducted in Agustus - November 2014, using data from register cohort of mother in 2009 - 2013 in working area of Kebonsari Public Health Center Madiun Regency. The technique for collecting data was using Poedji Rochjati Score Card which scored existing at the register cohort of mothers. The population was all pregnant women that exist in the register cohort of mothers Public Health Center in 2009 - 2013. The sample were taken with calculation formula of cross sectional research survey in proportion and in accordance with the criteria of inclusion number of 147 pregnant mothers.

Results: Of the 32 risk factors were analyzed, only 8 which has the effect of increasing Poedji Rochjati Score, and the only 1 that was statistically significant anemia. Of 8 risk factors, anemia was the biggest risk factor which capable to increase Poedji Rochjati Score a pregnant mothers troughout her pregnancy. The value of all the eight risk factors: anemia (6.737), number of Ante Natal Care (3.474), too many children $(1,261)$, pregnant again too quickly $(1,167)$, too old $(1,146)$, ever failed pregnancy $(1.114)$, Body Mass Index (1.107), too long to get pregnant again (1,051). Conclusion: Pregnant mothers with anemia had risk of 6.737 times for increased scores compared with pregnant mothers who were not anemia.
\end{abstract}

Keywords: low risk preganancies, high risk pregancies, very high risk pregnancies, increase Poedji Rochjati Score, card of Poedji Rochjati Score.

Correspondence: Siska Ditaningtias, Program Studi Magister Ilmu Kesehatan Masyarakat Fakultas Kesehatan Masyarakat Universitas Airlangga Surabaya. Email: siskaditaningtias@ gmail.com

\section{PENDAHULUAN}

Kehamilan risiko tinggi adalah kehamilan patologi yang dapat mempengaruhi keadaan ibu dan janin. Untuk menghadapi kehamilan risiko harus diambil sikap proaktif, berencana dengan upaya promotif dan preventif sampai dengan waktunya harus diambil sikap tegas dan cepat untuk dapat menyelamatkan ibu dan bayinya. Kriteria risiko tinggi yang digunakan di Jawa Timur menggunakan Kartu Skor Pudji Rochjati. Studi pendahuluan yang dilakukan pada Februari 2014 di Desa Balerejo wilayah kerja Puskesmas Kebonsari Kabupaten Madiun Propinsi Jawa Timur didapatkan data kehamilan risiko tinggi pada tahun 2012 sebesar 24,19\% dan tahun 2013 sebesar 30,77 \%. Demikian tingginya resiko kehamilan pada ibu dapat mengancam keselamatan bahkan dapat terjadi hal yang paling buruk yaitu kematian ibu dan bayi, maka perlu dilakukan upaya optimal guna mencegah atau menurunkan frekuensi ibu hamil yang berisiko tinggi serta penanganannya perlu segera dilakukan untuk menurunkan angka kematian ibu dan anak. Deteksi dini risiko tinggi pada ibu hamil dapat dilakukan melalui Kartu Skor Pudji Rochyati yang ada di dalam buku KIA. Skreening ibu hamil dilakukan 4x selama kehamilan, $1 \mathrm{x}$ di trimester pertama, $1 \mathrm{x}$ di trimester kedua, dan 2x di trimester ketiga. Kartu Skor 
Poedji Rochjati terdiri dari 28 faktor risiko yang dibagi menjadi 3 kelompok faktor risiko. Dari wawancara awal dengan beberapa Bidan di Puskesmas Kebonsari, mereka mengatakan bahwa ada beberapa hal yang sebenarnya di lapangan merupakan kejadian patologis (termasuk risiko tinggi) tetapi tidak ada di dalam Kartu Skor Poedji Rochjati, misalnya Ketuban Pecah Dini. Hal ini juga yang mendorong peneliti melakukan kajian lebih dalam faktor-faktor kehamilan risiko tinggi selain yang ada di dalam KSPR. Tujuan utama dilakukan penapisan faktor risiko adalah untuk mendeteksi wanita yang mempunyai risiko tinggi untuk mengalami komplikasi kehamilan, guna dirujuk ke tingkat pelayanan yang lebih tinggi. Penapisan dan rujukan dapat secara efektif menyelamatkan kehidupan. Deteksi dini dan pencegahan gawat darurat dapat dilakukan dengan pemeriksaaan antenatal yang baik. Pencegahan kelahiran pada wanita berisiko tinggi secara keseluruhan akan mengurangi angka kematian ibu sebesar 25\%. Faktor risiko adalah kondisi pada ibu hamil yang dapat menyebabkan kemungkinan risiko bahaya terjadinya komplikasi pada persalinan yang dapat menyebabkan kematian atau kesakitan pada ibu dan bayinya. Ada beberapa faktor risiko ibu hamil yang bisa menyebabkan kesakitan dan kematian ibu hamil dan bayi akan tetapi belum terdapat pada Kartu Skor Poedji Rochjati. Faktor risiko itu antara lain, Lingkar Lengan Atas, Indeks Massa Tubuh, status imunisasi TT, dan jumlah Ante Natal Care. Tujuan dari penelitian ini adalah Menganalisis faktor risiko peningkatan potensi kehamilan dari K1 hingga K4.

\section{BAHAN DAN METODE}

Berdasarkan metode, penelitian ini adalah penelitian Analisis data Sekunder atau disebut juga secondary data analysis atau existing statistic yaitu peneliti memanfaatkan data yang sudah matang yang dapat diperoleh pada instansi atau lembaga tertentu. Sumber data dalam Analisis Data Sekunder menggunakan dokumen yang dapat diambil dari instansi atau lembaga pemerintah maupun swasta. ${ }^{1}$ Penelitian ini menggunakan rancang bangun studi observasional (non eksperimental) jenis cross sectional dimana peneliti mencari hubungan dan pengaruh antara variabel independen dengan variabel dependen dengan melakukan pengukuran secara sesaat. ${ }^{2}$ Studi ini menggunakan data sekunder yang diperoleh dari kohort ibu. Lokasi penelitian dilaksanakan di Kecamatan Kebonsari Kabupaten Madiun Propinsi Jawa Timur. Waktu penelitian dimulai bulan Maret September 2014. Populasi adalah semua ibu hamil berdasarkan Kartu Skor Pudji Rochjati yang ada di kohort ibu wilayah kerja Puskesmas Kebonsari selama lima tahun terakhir. Besar sampel diambil menggunakan rumus penentuan besar sampe penelitian survey cross sectional secara proporsi sejumlah 178 , tetapi hanya 147 yang memenuhi kriteria inklusi. Pengambilan sampel dalam penelitian ini menggunakan systematic random sampling. Teknik yang digunakan adalah dengan metode dokumentasi kohort ibu. Sumber data menggunakan kohort ibu Puskesmas Kebonsari Kabupaten Madiun selama 5 tahun terakhir.

\section{HASIL DAN PEMBAHASAN}

Tabel 1. Faktor Risiko Penyebab

\begin{tabular}{lcc}
\multicolumn{1}{c}{ Variabel } & Frekuensi & Persentase \\
\hline anemia & 99 & 67,3 \\
anemia, APB & 1 & 0,7 \\
anemia, bengkak, TD tinggi & 10 & 6,8 \\
anemia, bengkak, TD tinggi, gemelli & 2 & 1,4 \\
anemia, gemelli & 2 & 1,4 \\
anemia, letak lintang & 1 & 0,7 \\
anemia, letak sungsang & 4 & 2,7 \\
anemia, post date & 2 & 1,4 \\
bengkak, TD tinggi & 3 & 2,0 \\
bengkak, TD tinggi, PEB & 1 & 0,7 \\
gemelli & 2 & 1,4 \\
IUFD & 1 & 0,7 \\
letak sungsang & 4 & 2,7 \\
PEB & 1 & 0,7 \\
post date & 1 & 0,7 \\
tidak ada & 13 & 8,8 \\
Total & 147 & 100,0 \\
\hline
\end{tabular}

Berdasarkan tabel 1 penyebab terbesar skor KSPR meningkat adalah anemia sebanyak $67,3 \%$.

\section{Identifikasi nilai dan kategori faktor risiko pada KI dan K4}

Tabel 2. Identifikasi nilai dan kategori faktor risiko pada K1

\begin{tabular}{ccc}
\hline Skor & Frekuensi & Persentase $(\%)$ \\
\hline 2 & 62 & 42,2 \\
6 & 42 & 28,6 \\
10 & 27 & 18,4 \\
14 & 16 & 10,9 \\
\hline Total & 147 & 100,0 \\
\hline
\end{tabular}

Berdasarkan tabel 2 menunjukkan bahwa, pada K1 sebanyak $42,2 \%$ ibu hamil memiliki kategori kehamilan risiko rendah dengan skor 2, 28,6\% ibu hamil memiliki kategori kehamilan risiko tinggi dengan skor $6,18,4 \%$ 
ibu hamil memiliki kategori kehamilan risiko tinggi dengan skor 10, dan 10,9\% ibu hamil memiliki kategori kehamilan risiko sangat tinggi dengan skor 14. Pada saat K1 kehamilan risiko tinggi yang paling banyak adalah dengan skor 6 . Total jumlah kehamilan risiko rendah adalah $42,2 \%$, kehamilan risiko tinggi $47 \%$, dan kehamilan risiko sangat tinggi $10,9 \%$.

Tabel 3. Identifikasi nilai dan kategori faktor risiko pada K4

\begin{tabular}{ccc}
\hline Skor & Frekuensi & Persentase $(\%)$ \\
\hline 2 & 4 & 2,7 \\
6 & 49 & 33,3 \\
10 & 47 & 32,0 \\
14 & 26 & 17,7 \\
18 & 15 & 10,2 \\
22 & 3 & 2,0 \\
26 & 3 & 2,0 \\
\hline Total & 147 & 100,0 \\
\hline
\end{tabular}

Berdasarkan tabel 3 menunjukkan bahwa, Pada K4 sebanyak $2,7 \%$ ibu hamil memiliki kategori kehamilan risiko rendah dengan skor $2,33,3 \%$ ibu hamil memiliki kategori kehamilan risiko tinggi dengan skor $6,32 \%$ ibu hamil memiliki kategori kehamilan risiko tinggi dengan skor $10,17,7 \%$ ibu hamil memiliki kategori kehamilan risiko sangat tinggi dengan skor $14,10,2 \%$ ibu hamil memiliki kategori kehamilan risiko sangat tinggi dengan skor $18,2 \%$ ibu hamil memiliki kategori kehamilan risiko sangat tinggi dengan skor 22 dan $2 \%$ ibu hamil memiliki kategori kehamilan risiko sangat tinggi dengan skor 26. Pada saat $\mathrm{K} 4$ kehamilan risiko tinggi paling banyak adalah dengan skor 6 . Total jumlah kehamilan risiko rendah adalah $2,7 \%$, kehamilan risiko tinggi $65,3 \%$, dan kehamilan risiko sangat tinggi $32 \%$.

\section{Identifikasi faktor risiko pada KI dan K4}

Tabel 4. Sepuluh teratas faktor risiko pada K1

\begin{tabular}{clcc}
\hline No & \multicolumn{1}{c}{ Variabel } & Frekuensi & Presentase \\
\hline 1 & Terlalu lama hamil lagi & 16 & $10,9 \%$ \\
2 & Terlalu lama hamil & 8 & $5,4 \%$ \\
& lagi, terlalu tua & & \\
3 & Terlalu tua & 7 & $4,8 \%$ \\
4 & Terlalu pendek & 6 & $4,1 \%$ \\
5 & Terlalu lama hamil & 5 & $3,4 \%$ \\
& lagi, terlalu banyak & & \\
& anak, terlalu tua & & \\
6 & Terlalu cepat hamil & 4 & $2,7 \%$ \\
& lagi, terlalu tua & & \\
7 & Anemia saja & 4 & $2,7 \%$ \\
8 & Terlalu cepat hamil & 3 & $2,0 \%$ \\
& lagi, pernah gagal & & \\
& kehamilan & &
\end{tabular}

\begin{tabular}{rlcc}
9 & $\begin{array}{l}\text { Terlalu cepat hamil } \\
\text { lagi }\end{array}$ & 3 & $2,0 \%$ \\
10 & $\begin{array}{l}\text { Pernah gagal } \\
\text { kehamilan }\end{array}$ & 3 & $2,0 \%$ \\
11 & Faktor risiko yang lain & 88 & $59,9 \%$ \\
\hline & Total & 147 & $100 \%$ \\
\hline
\end{tabular}

Berdasarkan tabel 4 menunjukkan bahwa, Faktor risiko terbanyak pada K1 adalah terlalu lama hamil lagi sebanyak $10,9 \%$.

Tabel 5. Sepuluh teratas faktor risiko pada saat K4

\begin{tabular}{|c|c|c|c|}
\hline No & Variabel & Frekuensi & Persentase \\
\hline & Anemia saja & 47 & 32 \\
\hline 2 & $\begin{array}{l}\text { Terlalu lama hamil lagi, } \\
\text { anemia }\end{array}$ & 9 & 6,1 \\
\hline 3 & Terlalu pendek, anemia & 6 & 4,1 \\
\hline 4 & $\begin{array}{l}\text { Terlalu lama hamil lagi, } \\
\text { terlalu tua, anemia }\end{array}$ & 5 & 3,4 \\
\hline 5 & Terlalu tua, anemia & 4 & 2,7 \\
\hline 6 & $\begin{array}{l}\text { Terlalu cepat hamil lagi, } \\
\text { terlalu tua, anemia }\end{array}$ & 4 & 2,7 \\
\hline 7 & $\begin{array}{l}\text { Terlalu cepat hamil lagi, } \\
\text { anemia }\end{array}$ & 4 & 2,7 \\
\hline 8 & Letak sungsang & 4 & 2,7 \\
\hline 9 & $\begin{array}{l}\text { Pernah gagal kehamilan, } \\
\text { anemia }\end{array}$ & 3 & 2,1 \\
\hline 10 & $\begin{array}{l}\text { Anemia, bengkak muka } \\
\text { dan tungkai beserta TD } \\
\text { tinggi }\end{array}$ & 3 & 2,1 \\
\hline \multirow[t]{2}{*}{11} & Faktor risiko yang lain & 58 & 39,5 \\
\hline & Total & 147 & 100 \\
\hline
\end{tabular}

Berdasarkan tabel 5 menunjukkan bahwa, Faktor risiko terbanyak pada K4 adalah anemia/kurang darah sebanyak $32 \%$. Kejadian terbanyak pada K1 adalah terlalu lama hamil lagi (primi tua sekunder) sebanyak 16 orang (10,9\%). Kejadian terbanyak pada K4 adalah anemia sebanyak 47 orang $(32 \%)$. Jika dilihat pada saat K1, kejadian anemia hanya sebesar $2,7 \%$ (4 orang). Dari data ini maka tampak bahwa kejadian anemia sangat banyak terjadi pada kunjungan K4. Artinya, sepanjang perjalanan kehamilannya, ibu hamil di wilayah kerja Puskesmas Kebonsari kemungkinan pola hidupnya buruk, tidak tahu, tidak patuh meminum tablet besi, kurang penyuluhan/promosi/pendidikan dari tenaga kesehatan setempat, tidak tahu bahwa orang hamil membutuhkan banyak zat besi, tidak memperhatikan lauk pauk dan sayur mayur saat makan sehari-hari, dan masih banyak lagi.

\section{Identifikasi Peningkatan Skor}

Sebagian besar responden mengalami peningkatan/ penambahan skor KSPR sepanjang kehamilannya yaitu sebesar 90,5\% (Tabel 6). 
Tabel 6. Peningkatan skor

\begin{tabular}{lcc}
\hline $\begin{array}{c}\text { Delta skor } \\
\text { (peningkatan potensi } \\
\text { kehamilan berisiko) }\end{array}$ & Frekuensi & $\begin{array}{c}\text { Persentase } \\
(\%)\end{array}$ \\
\hline Bertambah & 133 & 90,5 \\
Tetap/tidak bertambah & 14 & 9,5 \\
\hline Total & 147 & 100 \\
\hline
\end{tabular}

\section{Identifikasi nilai dan kategori faktor risiko pada KI dan K4}

Pada K1 sebanyak 42,2\% ibu hamil memiliki kategori kehamilan risiko rendah dengan skor 2, 28,6\% ibu hamil memiliki kategori kehamilan risiko tinggi dengan skor 6, 18,4\% ibu hamil memiliki kategori kehamilan risiko tinggi dengan skor 10, dan 10,9\% ibu hamil memiliki kategori kehamilan risiko sangat tinggi dengan skor 14. Pada saat K1 kehamilan risiko tinggi yang paling banyak adalah dengan skor 6 . Total jumlah kehamilan risiko rendah adalah $42,2 \%$, kehamilan risiko tinggi $47 \%$, dan kehamilan risiko sangat tinggi $10,9 \%$.

Pada K4 sebanyak 2,7\% ibu hamil memiliki kategori kehamilan risiko rendah dengan skor 2, 33,3\% ibu hamil memiliki kategori kehamilan risiko tinggi dengan skor 6, 32\% ibu hamil memiliki kategori kehamilan risiko tinggi dengan skor 10, 17,7\% ibu hamil memiliki kategori kehamilan risiko sangat tinggi dengan skor 14, $10,2 \%$ ibu hamil memiliki kategori kehamilan risiko sangat tinggi dengan skor $18,2 \%$ ibu hamil memiliki kategori kehamilan risiko sangat tinggi dengan skor 22 dan $2 \%$ ibu hamil memiliki kategori kehamilan risiko sangat tinggi dengan skor 26. Pada saat K4 kehamilan risiko tinggi paling banyak adalah dengan skor 6 . Total jumlah kehamilan risiko rendah adalah $2,7 \%$, kehamilan risiko tinggi $65,3 \%$, dan kehamilan risiko sangat tinggi $32 \%$. Apabila dibuat perbandingannya maka akan tampak seperti pada Tabel 7.

Tabel 7. Perbandingan Persentase Kategori Kehamilan Pada K1 dan K4

\begin{tabular}{lc}
\hline \multicolumn{1}{c}{ Variabel } & RR \\
\hline Terlalu cepat hamil lagi & $1,167(0,884-1,542)$ \\
Terlalu lama hamil lagi & $1,051(0,920-1,201)$ \\
Pernah gagal kehamilan & $1,114(0,839-1,480)$ \\
Indeks Massa Tubuh & $1,107(0,975-1,257)$ \\
Terlalu banyak anak & $1,261(0,179-8,888)$ \\
Terlalu tua & $1,146(0,339-3,877)$ \\
Kurang darah & $6,737(2,657-17,079)$ \\
Jumlah ANC & $3,474(0,473-25,542)$ \\
\hline
\end{tabular}

Peningkatan presentase kehamilan risiko tinggi sebanyak $18,3 \%$ dan kehamilan risiko sangat tinggi sebanyak $21,1 \%$ disebabkan karena masih ada $21,1 \%$ ibu hamil yang jumlah pemeriksaan Ante Natal Care nya $<4 \mathrm{x}$ sehingga tenaga kesehatan tidak bisa mengikuti dan mengawasi perkembangan kehamilan ibu tersebut. Jika tenaga kesehatan tidak mampu mengikuti perkembangan kehamilan seorang ibu hamil, maka risiko-risiko kehamilan pun tidak terdeteksi dengan baik dan lengkap. Selain karena faktor jumlah Ante Natal Care, disebabkan juga karena masih ada $35,4 \%$ ibu hamil yang Indeks Massa Tubuhnya tidak normal. Apabila Indeks Massa Tubuh ini lebih atau dibawah standar maka akan ada komplikasi-komplikasi yang terjadi seperti Berat Bayi Lahir Rendah (IMT < normal) dan bayi makrosomia atau bayi dengan diabetes mellitus (IMT> normal). Lingkar lengan yang $<23,5 \mathrm{~cm}$ sebanyak $14,3 \%$ juga mampu menyebabkan peningkatan kategori kehamilan risiko tinggi dan kehamilan risiko sangat tinggi dari K1 hingga K4. KEK mampu menyebabkan seorang ibu hamil mengalami anemia bahkan memperberat. Standar pelayanan minimal yang tidak terlaksana dengan baik, karena masih ada 3,4\% responden yang tidak diketahui status imunisasi TT nya, menjadi kemungkinan penyebab peningkatan prosentase kehamilan berisiko dari K1 hingga K4 di wilayah kerja Puskesmas Kebonsari.

\section{Identifikasi faktor risiko pada KI dan K4}

Faktor risiko terbanyak pada saat K1 adalah terlalu lama hamil lagi sebanyak 10,9\%. Artinya, 10,9\% ibu hamil di wilayah kerja Puskesmas Kebonsari tidak merencanakan kehamilannya dengan baik dan sehat. Kehamilan sebaiknya terencana. Perencanaan itu mengatur berapa tahun jarak antara anak pertama dan berikutnya. Tindakan tersebut mengurangi risiko yang membahayakan nyawa ibu dan bayi dalam kandungan. Salah satu kehamilan berisiko bila ibu hamil lagi saat anak yang terkecil berusia lebih dari sepuluh tahun. ${ }^{3}$ Kelompok itu dinamakan primi tua sekunder. Ibu dikatakan primi tua bila hamil pertama setelah menikah lebih dari empat tahun atau hamil pertama pada usia 35 tahun atau lebih. Primi tua dan sekunder termasuk kehamilan yang berisiko. Kehamilan dan persalinan membutuhkan proses adaptasi. Begitu juga pada ibu primi tua sekunder. Setelah lebih dari sepuluh tahun melahirkan anak terakhir, kemudian hamil lagi, rahim butuh proses adaptasi. Otot pada jalan lahir juga memerlukan penyesuaian. Saat adaptasi tersebut, ada beberapa kemungkinan yang muncul. Di antaranya, perdarahan atau janin mati dalam kandungan. Hal inilah yang menimbulkan risiko-risiko saat proses kehamilan dan persalinan. ${ }^{3}$ Walau demikian, ibu hamil tak boleh lantas pesimistis. Justru, ibu harus mempersiapkan diri. Caranya, lebih memperhatikan perawatan kesehatan saat menghadapi kehamilan risiko tinggi itu. Salah satu caranya, menjalani persalinan di rumah sakit (RS). Persalinan tidak bisa spontan, melainkan menjalani 
operasi Caesar. ${ }^{3}$ Kehamilan berisiko tinggi tak harus menjalani persalinan caesar. Dokter tetap akan mempertimbangkan kemungkinan persalinan spontan. Bila sekiranya cara tersebut membahayakan jiwa ibu dan bayi, dokter lebih memilih operasi. Sebelumnya dokter tentu akan memberitahukan hal itu kepada pasangan suami istri (pasutri) tersebut. Segala kemungkinan yang terjadi wajib diberitahukan biar pasutri yang memutuskan. Proses rujukan terencana seperti itu diharapkan menurunkan angka kematian ibu dan anak. Jangan lupa, rutin kontrol ke dokter atau bidan. Bila ada keluhan, bisa segera tertangani (putut/IPKB).

Hal-hal lain yang ditemui peneliti adalah, masyarakat di Kebonsari sebagian besar memiliki pekerjaan sebagai Tenaga Kerja Indonesia di luar negeri. Mereka bekerja tidak hanya satu tahun atau dua tahun melainkan bertahun-tahun bahkan puluhan tahun, meninggalkan anak dan istri atau suami. Pola seksual pun menunggu suami/istri pulang ke Indonesia baru melakukan hubungan seksual. Banyak yang terlena dengan lamanya bekerja di luar negeri sehingga keinginan untuk mempunyai anak kedua pun juga ikut tertunda.

Jarak kehamilan yang disarankan agar kehamilan berlangsung aman paling sedikit adalah 2 tahun, untuk memungkinkan tubuh ibu dapat pulih dari kebutuhan ekstra pada kehamilan dan laktasi. Jarak kehamilan yang terlalu dekat menyebabkan ibu memiliki risiko tinggi untuk mengalami perdarahan postpartum dan kematian ibu. Menurut penelitian yang dilakukan oleh Agudelo A.C dan Belizan J.M dan didukung oleh penelitian-penelitian sebelumnya, jarak kehamilan yang terlalu panjang (5 tahun) akan meningkatkan risiko untuk terjadinya preeklamsia/eklamsia, diabetes gestasional, perdarahan pada trimester ketiga dan juga menunjukkan peningkatan risiko untuk terjadinya kematian maternal, sehingga ibu dengan jarak kehamilan 5 tahun ini memerlukan perhatian khusus selama pemeriksaan antenatal.

Ibu hamil dengan persalinan terakhir 10 tahun yang lalu seolah-olah menghadapi kehamilan/persalinan yang pertama lagi. Umur ibu biasanya lebih bertambah tua. Kehamilan seperti ini biasanya terjadi pada anak pertama mati, janin didambakan dengan nilai sosial yang tinggi, anak terkecil hidup umur 10 tahun lebih, ibu tidak ber KB. Bahaya yang dapat terjadi pada ibu primi tua sekunder adalah persalinan berjalan tidak lancar, perdarahan pasca persalinan, muncul hipertensi, diabetes, dan lain-lain. ${ }^{4}$

Faktor risiko terbanyak pada K4 adalah anemia/kurang darah saja sebanyak $32 \%$ (47 orang). Pada K1 variabel anemia/kurang darah saja hanya sebesar 2,7\% (4 orang) tapi saat K4 naik secara signifikan sebanyak 29,3\% atau sebesar 11,75 kali lipat atau hampir 12x lipat kenaikan faktor risiko anemia saja dari K1 ke K4. Hal ini tidak semestinya terjadi. Hal ini kemungkinan besar disebabkan karena tidak adanya intervensi awal pada ibu hamil yang anemia sejak awal kehamilan, ketidakpatuhan ibu dalam mengkonsumsi tablet besi, ketidaktahuan ibu mengenai manfaat mengkonsumsi tablet besi, dan tidak adanya pengawasan dari tenaga kesehatan setempat tentang kepatuhan pasien mengkonsumi tablet besi, dan ketidaktahuan ibu hamil mengenai makanan apa saja yang mengandung zat besi yang sangat berguna di masa hamil.

Anemia (kurang darah) bisa dibawa sebelum kehamilan atau timbul setelah kehamilan berlangsung. Jika sebelum kehamilan sudah anemia (kurang darah), selagi hamil akan bertambah berat. Anemia (kurang darah) defisiensi zat besi paling sering dialami ibu hamil. Bisa akibat minimnya pemasukan unsur besi dari makanan ke tubuh entah lantaran makanan tersebut memang kurang unsur besinya atau karena adanya gangguan pencernaan sehingga unsur zat besi tak bisa di serap tubuh, bisa juga diakibatkan terlalu banyak zat besi yang keluar dari badan semisal karena perdarahan, seperti penyakit wasi yang kronis. ${ }^{5}$ Kadar Hemoglobin $\mathrm{(Hb})$ ibu sangat mempengaruhi berat bayi yang akan dilahirkan. Ibu hamil yang anemia (kurang darah) karena Hbnya rendah bukan hanya membahayakan jiwa ibu tetapi juga mengganggu pertumbuhan dan perkembangan serta membahayakan jiwa janin. Hal ini disebabkan karena kurangnya suplai nutrisi dan oksigen pada placenta yang akan berpengaruh pada fungsi placenta terhadap janin. Anemia (kurang darah) pada ibu hamil akan menambah risiko mendapatkan Bayi Berat Lahir Rendah (BBLR), risiko perdarahan sebelum dan pada saat persalinan, bahkan dapat menyebabkan kematian ibu dan bayinya, jika ibu hamil tersebut mengalami anemia (kurang darah) berat. ${ }^{6}$ Menurut Rukiyah, Anemia (kurang darah) juga menyebabkan rendahnya kemampuan jasmani karena sel-sel tubuh tidak cukup mendapat pasokan oksigen. ${ }^{7}$ Anemia (kurang darah) juga meningkatkan frekuensi komplikasi pada kehamilan dan persalinan. Risiko kematian maternal, angka prematuritas, berat badan bayi lahir rendah, dan angka kematian perinatal meningkat, perdarahan post partum lebih sering dijumpai pada wanita yang anemis dan lebih sering berakibat fatal, sebab wanita yang anemis tidak dapat mentolerir kehilangan darah. Kadar hemoglobin (Hb) ibu hamil sangat mempengaruhi berat bayi yang dilahirkan. Anemia (kurang darah) pada ibu hamil akan menambah risiko mendapatkan bayi berat lahir rendah (BBLR), risiko perdarahan sebelum dan pada saat persalinan, bahkan dapat menyebabkan kematian ibu dan bayinya, jika ibu hamil tersebut mengalami anemia (kurang darah) berat. ${ }^{6}$ Hal ini disebabkan karena kurangnya suplai darah 
nutrisi akan oksigen pada plasenta yang akan berpengaruh pada fungsi plasenta terhadap janin. Faktor risiko pada saat $\mathrm{K} 4$ merupakan akumulasi dari faktor risiko pada saat K1. Artinya, ketika ibu hamil sudah mempunyai satu atau beberapa faktor risiko pada saat $\mathrm{K} 1$, hal itu akan terus mengikuti sampai akhir kehamilan pada saat K4. Meskipun di tengah-tengah perjalanan kehamilan penyakitnya sembuh, itu tetap tidak akan menurunkan skor KSPR. Ibu hamil tersebut tetap akan dianggap berisiko meskipun risikonya hilang atau menurun, karena riwayatnya ibu hamil pernah mempunyai faktor risiko tersebut saat kehamilannya yang sekarang.

Hal lainnya terkait dengan faktor risiko pada K1 adalah, ketika masyarakat terlena akan gemilang gaji yang melimpah dengan bekerja sebagai Tenaga Kerja Indonesia di luar negri, mereka cenderung melupakan pola makan sehat dan bergizi. Bagi masyarakat adalah hal yang membanggakan adalah ketika bisa membangun rumah mewah hasil dari bekerja sebagai Tenaga Kerja Indonesia. Akan tetapi, tidak memperhatikan asupan nutrisi saat hamil. Masyarakat merasa sayang ketika uang itu dihabiskan untuk makan, mereka lebih senang dan bangga jika uang yang mereka hasilkan ada bentuknya yaitu rumah mewah. Kesadaran akan gizi dan nutrisi sangat kurang.

\section{Identifikasi peningkatan nilai faktor risiko dari KI ke K4}

Dari 147 responden, sebanyak 90,5\% mengalami kenaikan skor KSPR. Hal ini diluar kewajaran. Puskesmas Kebonsari sendiri memiliki target bahwa ibu hamil risiko tinggi dan ibu hamil risiko sangat tinggi tidak boleh lebih dari $20 \%$. Kemungkinan-kemungkinan penyebabnya adalah pola sosio demografi, aktifitas ibu hamil, kebiasaan ibu hamil, ketidak tahuan, kurangnya pengetahuan mengenai kehamilan risiko tinggi dan kehamilan risiko sangat tinggi dan bagaimana mencegahnya, keturunan, pola makan yang salah (jenis, jumlah, frekuensi), dan kurangnya informasi dari petugas kesehatan.

\section{Identifikasi besarnya nilai relative risk masing- masing faktor risiko}

Dari 32 faktor risiko, hanya 8 faktor risiko yang mempunya nilai RR (relative risk) > 1 . Dan hanya 1 variabel yang bermakna secara statistik yaitu variabel anemia (kurang darah). Ibu yang anemia (kurang darah) mempunyai risiko sebesar 6,737 kali lipat lebih besar untuk mengalami kenaikan skor KSPR dibandingkan dengan ibu yang tidak anemia (kurang darah).
Dari hasil penelitian ini, maka dapat kita simpulkan bahwa di wilayah kerja Puskesmas Kebonsari banyak ibu hamil mengalami anemia yang berisiko ke arah rendahnya kemampuan jasmani karena sel-sel tubuh tidak cukup mendapat pasokan oksigen. Pada wanita hamil, anemia meningkatkan frekuensi komplikasi pada kehamilan dan persalinan. Risiko kematian maternal, angka prematuritas, berat badan bayi lahir rendah, dan angka kematian perinatal meningkat.

Di samping itu, perdarahan antepartum dan postpartum lebih sering dijumpai pada wanita yang anemis dan lebih sering berakibat fatal, sebab wanita yang anemis tidak dapat mentolerir kehilangan darah. Dampak anemia pada kehamilan bervariasi dari keluhan yang sangat ringan hingga terjadinya gangguan kelangsungan kehamilan abortus, partus imatur/prematur), gangguan proses persalinan (inertia, atonia, partus lama, perdarahan atonis), gangguan pada masa nifas (subinvolusi rahim, daya tahan terhadap infeksi dan stres, produksi ASI rendah), dan gangguan pada janin (abortus, dismaturitas, mikrosomi, BBLR, kematian perinatal, dan lain-lain). ${ }^{8}$

Dengan adanya penelitian ini, diharapkan pimpinan Puskesmas Kebonsari dan Dinas Kesehatan setempat dapat mengantisipasi agar di kemudian hari kejadian anemia tidak lagi banyak yaitu dengan cara mengkonsumsi makanan bergizi seimbang dengan asupan zat besi yang cukup untuk memenuhi kebutuhan tubuh. Zat besi dapat diperoleh dengan cara mengkonsumsi daging (terutama daging merah) seperti sapi. Zat besi juga dapat ditemukan pada sayuran berwarna hijau gelap seperti bayam dan kangkung, buncis, kacang polong, serta kacang-kacangan. Perlu diperhatikan bahwa zat besi yang terdapat pada daging lebih mudah diserap tubuh daripada zat besi pada sayuran atau pada makanan olahan seperti sereal yang diperkuat dengan zat besi. Upaya pencegahan dapat dilakukan dengan pemberian suplemen $\mathrm{Fe}$ dosis rendah $30 \mathrm{mg}$ pada trimester ketiga ibu hamil non anemik ( $\mathrm{Hb}$ lebih=11g/dl),sedangkan untuk ibu hamil dengan anemia defisiensi besi dapat diberikan suplemenFe sulfat $325 \mathrm{mg} 60-65 \mathrm{mg}, 1-2$ kali sehari. Untuk yang disebabkan oleh defisiensi asam folat dapat diberikan asam folat $1 \mathrm{mg} / \mathrm{hari}$ atau untuk dosis pencegahan dapat diberikan $0,4 \mathrm{mg} / \mathrm{hari}$. Dan bisa juga diberi vitamin B12 100-200 mcg/hari. ${ }^{8}$

\section{SIMPULAN}

Skor terbanyak pada saat K1 adalah skor 2 sebanyak 62 orang $(42,2 \%)$ dan pada saat K4 adalah skor 6 sebanyak 49 orang $(33,3 \%)$. Kategori kehamilan terbanyak pada saat K1 adalah kehamilan risiko tinggi sebanyak 69 orang (47\%) dan pada saat $\mathrm{K} 4$ adalah kehamilan risiko 
tinggi sebanyak 96 orang $(65,3 \%)$. Faktor risiko terbanyak pada saat $\mathrm{K} 1$ adalah terlalu lama hamil lagi (primi tua sekunder) sebanyak 16 orang $(10,9 \%)$ dan pada saat K4 adalah anemia saja sebanyak 47 orang $(32 \%)$.

Sebanyak 90,5\% responden mengalami pe-ningkatan skor KSPR. Dari 32 faktor risiko yang dianalisis, terdapat variabel 8 yang mempunyai nilai relative risk > 1 , dan hanya 1 variabel yang bermakna secara statistik, yaitu kurang darah yang mempunyai nilai RR 6,737 (2,657-17,079).

Tidak didapatkan faktor risiko kehamilan baru selain yang ada pada KSPR yang bermakna secara statistik. Tidak ada rekommendasi untuk faktor risiko kehamilan baru selain yang ada pada KSPR.

\section{DAFTAR PUSTAKA}

1. Martono N. Metode Penelitian Kuantitatif Analisis Isi dan Analisis Data Sekunder. Jakarta: PT Raja Grafindo Persada; 2012.

2. Sastroasmoro S. Dasar-dasar Metodologi Penelitian Klinis. Edisi ke-3. Jakarta: Sagung Seto; 2008.

3. Rochjati P. Skrining Antenatal Pada Ibu Hamil. Surabaya: Airlangga University Press; 2003.

4. Rochjati P. Skrining Antenatal Pada Ibu Hamil. Surabaya: Airlangga University Press; 2011.

5. Solihah L. Panduan Lengkap Hamil Sehat. Yogyakarta: Diva Press; 2008.

6. Anonim. Buku Kesehatan Ibu dan Anak. Jakarta: Departemen Kesehatan RI; 2008.

7. Rukiyah AY. Asuhan Kebidanan IV (Patologi). Jakarta: Trans Info Media; 2010.

8. Saifuddin AB. Pelayanan Kesehatan Maternal dan Neonatal. Edisi ke-1. Jakarta: Yayasan Bina Pustaka Sarwono Prawirohardjo; 2002. 